From:

The Handbook of Evolutionary Psychology

Edited by David Buss

John Wiley and Sons, Hoboken, NJ, 2005

CHA P TER 32

\title{
Evolutionary Psychology and Mental Health
}

RANDOLPH M. NESSE

\begin{abstract}
A N evolutionary perspective revolutionized our understanding of behavior over a generation ago, but most mental health clinicians and 1 researchers still view evolution as an interesting or even threatening alternative, instead of recognizing it as an essential basic science for nderstanding mental disorders. Many factors explain this lag in incorporating new knowledge, but the most important may be the clinician's pragnatic focus on finding ways to help people now. Evolutionary researchers have not found a new treatment for a single mental disorder, so why should mental health clinicians and researchers care about evolutionary psychology (EP)? This chapter attempts to answer that question. The greatest value of an evolutionary approach is not some specific finding or new therapy, but is instead the framework it provides for uniting all aspects of a biopsychosocial model. Perhaps equally valuable is the deeper empathy fostered by an evolutionary perspective on life's vicissitudes. An evolutionary perspective does not compete with other theories that try to explain why some people have mental disorders and others do not. Instead, it asks a fundamentally different question: Why has natural selection left all humans so vulnerable to mental disorders? At first, the question seems senseless. Natural selection shapes mechanisms that work, so how can it help us understand why the mind fails? It is also difficult to see how it is useful to know why we are vulnerable. Who cares why all humans are vulnerable to depression, when the goal is to help the individual who is depressed here and now? Surmounting these conceptual hurdles is a challenge that requires time and effort. Researchers and clinicians will make the effort when they know what evolution offers to the understanding of mental disorders.
\end{abstract}

\section{WHAT EVOLUTION OFFERS}

Many have contributed to the grow th of evolutionary psychiatry, but the contributions are in diverse sources and not always consistent. Early applications of 
Table 32.1

Eight Fundamental Contributions

\section{An evolutionary perspective on mental disorders:}

1. Asks new questions about why natural selection has left us all vulnerable to mental disorders, questions with six kinds of possible answers,

2. Offers the beginnings of the kind of functional understanding for mental health professions that physiology provides for the rest of medicine,

3. Provides a framework for a deeper and more empathic understanding of individuals,

4. Explains how relationships work,

5. Provides a way to think clearly about development and the ways that early experiences influence later characteristics,

6. Provides a foundation for understanding emotions and their regulation,

7. Provides a foundation for a scientific diagnostic system,

8. Provides a framework for incorporating multiple causal factors that explain why some people get mental disorders while others do not.

ethology to mental disorders (McGuire \& Fairbanks, 1977; White, 1974) gave rise to more specific and comprehensive evolutionary approaches (McGuire \& Troisi, 1998; Pitchford, 2001; Stevens \& Price, 1996; Wenegrat, 1990). Several books cover specific conditions (Baron-Cohen, 1995, 1997; Gilbert, 1992; Wenegrat, 1995), while others take a more anthropological approach (Fabrega, 2002). Many articles address specific mental disorders, and some provide a new foundation for defin ing the categories that describe disorders (Cosmides \& Tooby, 1999); Wakefield, 1992). Many chapters in this Hontbook and many general books about EP tackle one or another mental disorder (Badcock, 2000; Barkow, Cosmides, \& Tooby, 1992; Barrett, Dunbar, \& Lycett, 2002; Buss, 1994, 1995, 2003, 2004; Craw ford, Smith, \& Krebs, 1987; Gaulin \& McBurney, 2001; Wright, 1994). The ideas in these sources are too many and too diverse to even list, but many can be summarized in a list of eight fundamental contributions that an evolutionary perspective offers to psychiatry and clinical psychology (Table 32.1). A brief summary of each sets the stage for considering specific disorders.

\section{Exr'laining Vulnerability to Mental Disorders}

The task of explaining why we are vulnerable to mental disorders is no different from that of explaining why we are vulnerable to physical diseases. The tendency in both cases has been to oversimplify the problem by attributing vulnerability to the limited powers of natural selection. These limits are important explanations for some diseases, but there are five other possible reasons that the body and mind are not better designed, starting with the mismatch between our bodies and our environments (Nesse \& Williams, 1994; Williams \& Nesse, 1991).

Mismatch Most common chronic diseases are caused by novel environmental factors. For instance, atherosclerosis and breast cancer are prevalent now because our bodies are not well designed for life in a modern environment (Eaton et al., 2002). Whether rates of mental disorders are also increasing remains uncertain. An international effort to gather prevalence data on mental disorders from 72,000 interviews in 14 countries (Kessler \& Ustun, 2000) uses urban or 
rural agricultural sites. No comparable effort is estimating disorder rates in hunter-gatherer populations. This is unfort unate because such studies may not be possible in the next generation, but understandable because of the methodological obstacles.

Mental disorders are of ten blamed on the modern environment. When reading and writing were first spreading, Burton attributed melancholy to excessive study and "too little Venus" (Burton, 1624/1931). Much more recently, retrospective data seemed to suggest that depression rates were increasing rapidly with each generation (Cross-National Collaborative (roup, 1992). However, data gathered using consistent questions in the same population over recent decades showed no such increase (J. M. Murphy, Laird, Monson, Sobol, \& Leighton, 2000). For drug and alcohol problems, the story is more clear-cut. The rapid spread of alcohol-making technology changed our world in ways our species has not yet adapted to (Institute of Medicine, 1987), although selection may have increased the frequency of a defective aldehyde dehydrogenase gene that may protect Asian populations from alcoholism (M. Smith, 1986).

Infection and Coevolution Infections persist because our every evolutionary advance to escape bacteria and viruses is matched by their far faster evolution (A. S. Brown et al., 2004; Ewald, 1994). Furthermore, the defenses that protect us, especially inmune responses, tend to cause problens thenselves. Some mental disorders may result from arms races with pathogens and their autoimmune sequelae. For instance, some cases of obsessive-compulsive disorder may result from streptococcal-induced autoimmune damage to the caudate nucleus (Swedo, Leonard, \& Kiessling, 1994). Prenatal exposure to infection nay predispose to schizophrenia (Ledgerwood, Ewald, \& Cochran, 2003) as suggested by increased rates of schizophrenia in babies born during influenza epidemics (Kunugi et al., 1995) and a sevenfold risk increase for babies born to mothers who had influenza during the first trimester (A. S. Brown et al., 2004). Infectious causes have been proposed for a wide range of mental disorders, especially af fective disorders (Ewald, 2000).

A more insidious result of rapid coevolution arises from competition within our species that induces more and more extreme traits, especially those that lead to winning social competitions (Alexander, 1974; Humphrey, 1976; Whiten \& By rne, 1997). If sexual selection has shaped mental traits (Miller, 2000), this could account for vulnerability to certain disorders, especially those associated with creativity (Richards, Kinner, Lunde, \& Benet, 1988; Shaner, Miller, \& Mintz, 2004). Even aside from competing for partners, competing for stat us absorbs vast human energy (Barkow, 1989; Veblen, 1899) and gives rise to much suffering from envy and the negative emotions associated with failures (Gilbert, Price, \& Allen, 1995). Such emotional tendencies might well result from arms races that often leave us in zero-sum competitions (Frank, 1999).

Trate-Offs Design trade-offs make perfection impossible for any trait, natural or human made. A car that gets 60 miles per gallon will not get to 60 miles per hour in 6 seconds. We humans could run faster if our legs were longer, but our bones would be more fringile. We could have less anxiety, but only at the cost of being more likely to be injured or killed. 
Constraints Systems shaped by natural selection are subject to several special constraints, especially path dependence. For instance, we are stuck with eyes whose vessels and nerves rum between the light and the retina. Furthermore, in contrast to consciously created designs, biological designs are products of selection that involve limited options, random effects, inaccurate transmission of the DNA code, and the vagaries of interaction effects with different environments. Far from assuming that everything is adaptive, an evolutionary approach cal ls attention to defective and substandard designs that result from multiple trade-offs, constraints, and errors.

Selection Is for Reproductive Success. Not Health Many imagine that selection shapes bodies and minds that are healthy, long-lived, and cooperative. It does, when those traits increase reproductive success (RS). However, a gene that decreases health, longevity, or cooperativeness will nonetheless spread if it increases RS. Such genes are likely responsible for many of our least valued characteristics, such as bitter competition, envy, greed, and unquenchable sexual desire and jealousy (Buss, 2000). The differences between the sexes arise largely because different reproductive strategies shape different physical and mental traits, even at the expense of longevity and individual well-beingr (Cronin, 1991; Daly \& Wilson, 1983; Geary, 1998; Kruger \& Nesse, 2004).

Defenses Pain, cough, fever, and other protective responses are unpleasant but useful responses that protect us from danger and loss. The prevalent tendency to confuse these defenses with diseases and defects has been called "The Clinician's Illusion" (Nesse \& Williams, 1994). Most physicians know that cough and inflammation are adaptations, but the utility of fever, diarrhea, and anxiety is less widely recognized. A naïve view sees our vulnerability to negative emotions as examples of poor design. But natural selection does not care a fig for our happiness; it just mindlessly shapes whatever emotional tendencies increase RS (Nesse, 1991a; Tooby \& Cosmides, 1990). While positive emotions are useful in situations where energy and risk-taking pay off (Fredrickson, 1998), they can be fatal in dangerous situations (Nossc, 2004).

Summing Lip Six Causes Some evolutionary approaches to mental disorders emphasize one of the preceding six possible explanations. For instance, some authors attribute much psychopathology to living in a modern environment (Cilantz \& Pearce, 1989); others emphasize infection (Ewald, 2000), constraints, trade-offs, or path dependencies (Crow, 1997; Horrobin, 1998). Others propose that mental disorders persist because of fitness benefits, even for conditions such as schizophrenia (J. S. Allen \& Sarich, 1988; Shaner et al., 2004), bipolar disorder (Wilson, 1998), and suicide (deCatanzaro, 1980). The resulting confusion is substantial for those in the field and overwhelming for others.

While the human mind prefers monocausal explanations, a full evolutionary explanation for one disorder may include several different factors. For example, vulnerability to depression may arise from novel aspects of modern life, from infection, from constraints and trade-offs, and because low mood may be a defense that can increase $R S$ at the expense of personal happiness. Far from offering a 
simplistic approach to the causes of mental disorders, an evolutionary perspective provides a framework for organizing the genuine complexity into a biopsychosocial perspective (Weiner, 1998).

\section{An Evolutionary Framework for Understanding Human BEHAVIOR AND EMOTIONS}

When a patient comes to the general medical clinic with cough or kidney failure, the physician knows that cough is a protective response and that the kidney filters out toxins and regulates salt and water balance. By contrast, when a patient comes to a mental health clinic with a phobia, the utility of anxiety may never be considered. When someone comes with jealousy, consideration of its normal functions is unlikely. Mental health professionals lack a body of knowledge about normal emotional functions comparable to the understanding physiology offers to general medicine. EP is beginning to provide this missing body of knowledge, as shown by the chapters in this Handbook, and by evolutionary perspectives on motivation (French, Kamil, \& Leger, 20(0)), emotion (Plutchik, 2(0)3), and specific topics such as grief (Archer, 1999).

\section{UNIDERSTANDING INDIVILUAL. LIVIES}

EP can bring information about an individual's idiosyncratic values, goals, and life situations into a scientific framework. Consider John, a depressed 2()-year-old man who works two jobs in local stores to support his disabled mether. When he was 14 , his dying father made him promise to take care of his mother always. He has been doing that ever since, but with increasing resentment and depression. These three sentences give more insight into his depression than a dozen demographic variables and a brain scan. An evolutionary understanding of motivation can begin to bring such information into a nomothetic framework based on behavioral ecology categories of life history effort. The trade-offs among these categories are as universal as they are problematic (Krebs \& Davies, 1984; Stearns, 1992). No solution can be perfect, and the conflicts account for much human suffering (Chisholm, 1999; Low, 20(0); E. A. Smith \& Winterhalder, 1992; Sterelny \& Griffiths, 1999). Understanding these trade-offs fosters realistic clinical thinking and enhances empathy for the vicissitudes of people's lives.

\section{RELATIONSHIPS}

EP's greatest contribution may be a deeper understanding of relationships. For instance, Bowlby's (1969) insights about the evolutionary functions of attachment have been extended by suggestions that apparently "abnormal" kinds of attachment may represent alternative strategies for infants to get resources from mothers in difficult circumstances (Belsky, 1999; Chisholm, 1996) and a deeper understanding of women's reproductive strategies in general (Hrdy, 1999). Analysis of mutually beneficial reciprocal exchanges has led to extensive studies of economic games (Fehr \& Fischbacher, 20(1)3) that illuminate the origins of the social emotions (Fessler, in press; Fiske, 1992; Henrich \& Gil-White, 20(01). However, interpreting all human relationships as calculated exchanges ignores 
aspects of human behavior that are essential to understanding mental disorders, such as our capacities for moral action and the emotions of pride and guilt (Katz, 2000). Selection may have shaped capacities for conmitment that are superior to rational calculation (Frank, 1988; Gintis, 2000; Nesse, 2001a).

Psychodynamics Freud's theories are ridiculed because some are wrong and because psychoanalysis is not reliably effective. However, the reality of repression is a profound fact of human nature that needs an evolutionary explanation (Badcock, 1988; Sulloway, 1985), along with phenomena such as the Oedipus complex (Ericson, 1993). Trivers and Alexander separately suggested that self-deception is a strategy for deceiving others (Alexander, 1975; Trivers, 1976, 2000), but people also may repress the sins of others to preserve valuable relationships (Nesse, 1990b). Closely related is Trivers's (1974) insight that regression may be an effective strategy used by offspring to manipulate their parents into providing resources that would be appropriate only if they were younger or sick. His more general theory of parent-offspring conflict is the neglected foundation for understanding many childhood disorders. Attempts to provide an evolutionary foundation for psychodynamics are developing (Badcock, 1988; Slavin \& Kriegman, 1992; Sulloway, 1985) but remain relatively unappreciated by psychoanalysts, perhaps because an evolutionary view fosters skepticism that undermining repression will be helpful routinely (Slavin \& Kriegman, 1990).

Development Developmental psychology now offers sophisticated assessments of extensive data about what children do at different stages of life and how these phenomena vary across cultures. It increasingly takes evolution into account (Bateson \& Martin, 2000; Geary \& Bjorklund, 2000; Rutter \& Rutter, 1993). In the midst of a burst of interest in facultative developmental mechanisms and their role in evolution (Hall, 1998; West-Eberhard, 2003), evolutionary psychologists have begun looking for mechanisms that use environment inputs to adjust developmental pathways. An obvious facultative adaptation is the regulation of female reproductive onset by fat stores (Surbey, 1987). Less well supported are proposals that early father absence induces early reproduction (Belsky, Steinberg, \& Draper, 1991; Draper \& Harpending, 1982; Surbey, 1990). A possible adaptation with particular relevance for mental disorders is the adjustment of the gain in the hypothalamic pituitary axis system in response to early stress and the transmission of this sensitivity across the generations by maternal influences on fetal brain development (Essex, Klein, Eunsuk, \& Kalin, 2002; Teicher et al., 2003).

\section{Emotions and the Emotional Disorders}

Most mental disorders are emotional disorders. People come for treatment because they experience anxiety, depression, anger, or jealousy. Many assume that such negative emotions are abnormal, but they are useful, at least for our genes. People with depression and anxiety are so obviously impaired that it is difficult to see how such emotions could be useful. However, selection has shaped emotion regulation mechanisms that often give rise to normal but useless suffering (Nesse, 2004, 2005). An evolutionary foundation for studies of emotions is now routine (Ekman, 1992; Nesse, 1990a; Plutchik, 2003; Tooby \& Cosmides, 1990) and 
recognition is growing that emotions are special states shaped by selection to give advantages in fitness-significant situations that have recurred over evolutionary time.

\section{DIAGNOSIS}

When is an emotion abnormal? The criteria for psychiatric diagnoses are based on intensity, duration, and associated disability (American Psychiatric Association, 1994). The extremes are abnormal, but without knowing the functions of emotions, the line between normal and abnormal remains subjective (D. Murphy \& Stich, 2000; Nesse, 2001b; Troisi \& Mc(juire, 2002; Wakefield, 1992). The lack of an evolutionary foundation fosters serious errors including describing continuous emotions as categories and neglecting abnormal conditions characterized by excess positive or deficient negative emotions. In addition, diagnostic criteria do not consider the appropriateness of an emotion to the situation. If general medicine made diagnoses according to the strategy used in psychiatry, it would diagnose abnormal cough disorder based on cough frequency and severity without considering whether the cough was a normal response in certain situations. Far from genuinely atheoretical, the Diagnostic and Statistical Manual of Mental Disorders system (DSM; American Psychiatric Association, 1994) fosters a crude biological view (Horwitz, 2002).

Many agree that the DSM system inhibits understanding (Phillips, First, \& Pincus, 2003), and several authors have suggested how evolutionary principles can help to make diagnoses more scientific. D. Murphy and Stich (2000) take the DSM to task for its atheoretical approach and suggest distinguishing disorders that arise from brain abnormalities from those that arise from normal brains exposed to novel environments. They propose categories based on the presumed modularity of cognitive design. Wakefield (1992) offers a strong critique of the DSM, using the concept of "harmful dysfunction" to clarify what is and is not a disorder. This sophisticated evolutionary analysis of psychiatric diagnosis argues that it is essential for mental as well as physical disorders to separate normal from abnormal phenomena based on whether they are harmful and whether they arise from a dysf unction. This sophisticated understanding of evolutionary function is the scientific foundation for future psychiatric diagnostic systems (Wakefield, this volume).

An evolutionary view highlights the central flaw in the DSM criteria; they do not reflect the most basic distinction in medical diagnosis: that between diseases and symptoms of diseases. Negative emotions such as anxiety and sadness are useful capacities shaped by natural selection. Determining when they are abnormal requires understanding when and how they are useful.

An approach based on Darwinian medicine, following Wakefield, suggests global categories of mental problems based on answers to three questions: (1) Are cognitive and brain mechanisms normal or defective? (2) Do the symptoms arise from novel aspects of the environment, and (3) Are the symptoms in the interests of the individual, his or her genes, or neither? The resulting categories are:

1. Emotional, cognitive, or behavioral responses that arise from normal systems: a. Useful responses that may be aversive (ordinary anxiety and anger).

b. Normal responses that benefit the individual's genes, at the expense of the individual's interests. 
c. Responses that arise from normal system but that are not useful in the particularinstance.

d. Normal responses that are useless or harmful now but would not have been in the ancestral environment.

e. Normal responses that do not harm the individual but that are defined as abnormal by a group or culture.

2. Symptoms arising from abnormal regulation of a normal emotion or capacity.

a. Specific defects, genetic or acquired, account for the dysregulation (causation from below, hardware problems).

b. Dysregulation arising from social dilemmas or complexities (cinusation from above, software problems).

c. Extremes of a trait distribution that increase vulnerability.

3. Abnormalities of behavior, cognition, and emotion that arise from fundamental brain or cognitive abnormalities not primarily involved with systems that regulate emotion and behavior (e.g., lead poisoning).

\section{INDIVIDUAL DIFFERENCES}

Most psychiatric research attempts to explain individual differences. Despite growing agreement on the importance of gene-environment interactions (Kendler, Kuhn, \& Prescott, 2014; Ridloy, 2003; Rutter \& Rutter, 1993), major disagreenents persist about why some people get ill and others do not. Different authorities cmphasize different causal factors (genetic, developmental, situational, etc.). Far from emphasizing genetic differences, an evolutionary view provides a framework that highlights the relationships among all factors and levels. It also contributes strategies for avoiding some simple mistakes.

Much misunderstanding arises from confusing attempts to explain the existence of a trait with attempts to explain variations in a trait. It is senscless to ask whether a rectangle is caused more by its length or its width. However, rectiongles can vary in area only if their width or length (or both) changes. Likewise, variations among individuals can result only from differences in genes, differences in environments, and the interactions between them. The proportion of variance attributable to each component is not fixed, but varies depending on the particular environment and the range of genotypes. Preoccupation with nature versus nurture has distracted attention from the many different routes to a disorder. An evolutionary approach fosters simultaneous consideration of the many factors that may explain individual variation in a trait, some of which are listed in Table 32.2.

The task of accounting for individual differences should not be reduced to arguing about the relative importance of one factor compared to another. It is, instead, the challenge of explicating how each contributes to individual differences in a particular trait and how their contributions to a particular trait may be different not only between families, populations, or cultures, but even between individuals. The responsible factors may be mainly genetic in one individual and mainly environmental in another. This has practical implications for mental health research. For instance, we need to take seriously the possibility that many different genes contribute to depression vulnerability by many different routes. 
Table 32.2

Twelve Sources of Individual Differences

1. Additive genetic differences among individuals that result in phenotypic differences (in this environment)

2. Variation resulting from Gene $x$ Environment interactions

3. Variation resulting from Gene $x$ Gene interactions

4. Assortative mating-nonrandom mating increases or decreases trait variance

5. Random factors in development, such as the stochastic paths of neuron migration

6. Effects of cues that influence development via facultative mechanisms to a trajectory suited to the particular environment, such as early heat exposure influencing the number of adult sweat glands

7. Effects of trauma, toxins, and other environmental exposures outside the range of normal that damage the organism or distort its development

8. Effects of environmental factors that influence the organism "top-down" via perceptual experience without resulting in damage or acting via a specific facultative mechanism

9. Effects of environmental factors that influence the organism from the "bottom-up" that are neither damaging nor mediated via facultative adaptations

10. Effects of individual learning that facilitate flexible coping with current aspects of the environment

11. Experiences shared within a culture that are incorporated into values and emotional proclivities that may be difficult to change later (such as values or sexual attitudes)

12. Experiences shared within a culture whose effects account for variation that changes readily when conditions change

\section{SPECIFIC DISORDERS}

An evolutionary perspective calls attention to a distinction that is fundamental and well recognized in most of medicine, but unaccountably neglected in psychiatry. Some medical conditions, such as cancer and epilepsy, are diseases that arise from some abnormality in the body's mechanisms, while others, such as pain and cough, are protective responses. Some mental disorders, such as schizophrenia and autism, are almost certainly specific diseases or clusters of diseases, while others, such as depression and panic disorder are fundamentally different in that they are useful protective mechanisms, albeit ones that readily go awry. Not all mental disorders are emotional disorders, but many are, and they deserve consideration together.

\section{EMOTIONAL DISORDERS}

Most mental disorders are emotional disorders, but they are not yet based on knowledge about the origins and functions of emotions. Instead, intense or prolonged negative emotions are said to be abnormal, irrespective of the situation, while deficits in negative emotions and excesses of positive emotions are rarely recognized as disorders. An evolutionary perspective provides a more balanced view.

Anxicty Disorters Although anxiety can be useful, a dry mouth and tremor when standing before a large group seem worse than useless. Likewise, the symptoms of panic may help escape from a lion, but they are unhelpful in a grocery store. We now have a vast amount of knowledge about the responsible brain 


\section{Evolutionizing Tradition al Disciplines of Psychology}

mechanisms, but no comparable body of knowledge about the evolutionary origins and utility of social anxiety or panic (Nesse, 1987). Similarly, hundreds of studies document every aspect of excessive anxiety states, but only a handful look for states of deficient anxiety, the hypophobias (Marks \& Nesse, 1994). One study tried to confirm that fear of heights often results from severe falls early in life. It found adult fear of heights in $18 \%$ of the control group but only $3 \%$ of the group that had experienced a fall early in life. Those with hypophobia early in life still had deficient anxiety decades later (Poulton, Davies, Menzies, Langley, \& Silva, 1998).

Anxiety illustrates the diversity of the body's regulation mechanisms (Barlow, - 1988; Marks, 1987; Poulton \& Menzies, 2002; Stein \& Bouwer, 1997). For instance, rigid defensive responses to fixed cues, such as chicks hiding from hawk-shaped shadows, are useful when a correct response to the first encounter is essential, but they result in many false alarms and do not protect against novel dangers. Flexible learning mechanisms protect against novel dangers but may fail during a crucial initial exposure, and they are prone to result in phobias. Social learning is another solution. Infant rhesus monkeys show no innate fear of snakes; however, a single observation of another monkey displaying fear of snakes induces longlasting avoidance. Watching another monkey display fear of a flower induces no such fear (Mineka, Keir, \& Price, 1980).

Exposure treatment is effective for phobias, but the fear response is not unlearned (Barlow, 1988; Foa, Steketee, \& Ozarow, 1985; Marks \& Tobena, 1990). Instead, a new cortical process suppresses the fear response (Quirk, 2002). Exposure to danger disrupts this suppression. Thus, the great flood in Moscow caused the reemergence of previously extinguished fears in Pavlov's dogs. This may reflect a constraint in a path-dependent mechanism; simple unlearning apparently may be inpossible.

Other fears cannot be extinguished. For instance, posttraumatic stress disorder (PTSD) illustrates one-time learning of the strongest sort. A single life-threatening experience induces a subsequent terror response to any cue that suggests a recurrence of the dangerous situation (Breslau, Davis, \& Andreski, 1995). Proximate science is steadily honing in on the mechanisms that account for this syndrome (Pitman, 1989; Yehuda, Halligan, Golier, Grossman, \& Bierer, 2004), but it has been more difficult to find ways to differentiate alternative evolutionary hypotheses. PTSD could result from damage to mechanisms not designed to cope with such extreme situations. However, nearly dying is so important to fitness that it might well have shaped a one-time learning mechanism that gives rise to the symptoms of posttraumatic stress that might help prevent a recurrence.

Fear has distinct subtypes that seem to have been partially differentiated from generic anxiety to cope with domain-specific challenges (Marks \& Nesse, 1994). For instance, panic flight is just the ticket to escape from a predator, but frozen immobility is superior when teetering on a cliff. Social anxiety is present in most people (Cilbert, 2001; Leary \& Kowalski, 1995), and people who lack it are often insufferable, even if they do not qualify for a psychiatric diagnosis. We wonder how they would have fared in small hunter-gatherer groups. The characteristics of subtypes of anxiety map well onto the challenges posed by different threats.

The smoke detector principle helps to explain some apparent peculiarities of the mechanisms that regulate anxiety and other defenses (Nesse, 2005; Stein \& Bouwer, 1997). Because most anxiety responses are inexpensive and protect 
against huge potential harms, an optimal system will express many alarms that are unnecessary in the particular instance, but nonetheless perfectly normal. This suggests that using drugs to block defenses may be safe in most instances but that in some situations blocking a defense may be fatal.

Moot Disorders The utility of sadness and depression is less obvious than for anxiety, but Bibring (1953) long ago suggested that depression signaled the need to detach when libido persists in a connection to an unrewarding object. Hamburg, Hamburg, and Barchas (1975) and Klinger (1975) described how emotions regulate goal pursuit more generally, with inability to reach a goal first arousing aggressive attempts to overcome an obstacle, then low mood motivating disengagement. If the person does not give up, the negative affect escalates into depression. This principle, now confirmed by much research (Brickman, 1987; Carver \& Scheier, 1990, 1998; Emmons \& King, 1988; Janoff-Bulman \& Brickman, 1982; Little, 1999; Wrosch, Scheier, \& Miller, 2003), provides the foundation for a more general approach to mood as a mechanism that allocates effort proportional to propitiousness (Nesse, 1991b, 2000). When payoffs are high, positive mood increases initiative and risk-taking. When risks are substantial or effort is likely to be wasted, low mood blocks investments. In this perspective, ordinary episodes of sadness and low mood motivate changing behavioral strategies (Watson \& Andrews, 2002). If no alternative is found and the goal is essential, persistence may result in depression (Klinger, 1975; Wrosch, Scheier, \& Carver, 2003).

Observations of chickens and monkeys who lost their positions in the hierarchy have suggested a view of depression as "involuntary yielding" that protects against continuing attack (Gilbert, 1992; Sloman, Price, Gilbert, \& (Gardner, 1994). This is consistent with data showing that stressful events cause depression mainly if they are characterized by humiliation and/or being trapped in an impossible quest (G. W. Brown, Harris, \& Hepworth, 1995; Kendler, Hettema, Butera, Gardner, \& Prescott, 2003). Also related is the suggestion that sex differences in depression may arise from the male tendency to strive for position and resources, leaving many women vulnerable to depression because they have fewer options (Gilbert, 1992; Wenegrat, 1995).

Depression has also been viewed as a social manipulation (Hagen, 2002; Watson \& Andrews, 2002). Hagen sees postpartum depression as a "blackmail threat" to abandon the infant, but other theories can also explain the association of postpartum depression with poor resources and relationships. In a related but more general view, Watson and Andrews (2002) suggest that depression facilitates "social navigation" by signaling that current strategies are failing and new directions are needed. This approach echoes psychoanalyst Emmy (jut's (1989) work on productive and unproductive depression. Nettle (2004) notes inadequacies of the social navigation hypothesis and emphasizes the possible adaptive value of neuroticism.

DeCatanzaro (1980) proposed that suicide can be adaptive if an individual has no chance for reproduction but can increase fut ure reproduction of kin by ceasing to use resources that they could use instead. Data showing that suicides are more conmon in old and sick people are consistent; however, alternative explanations are available, separation from kin does not protect against suicide, and there are no animal examples. In a reverse twist on this perspective, the benefits of social support result more from help given than help received. Individuals who provide help to others have higher mood and increased longevity (R. Brown, Dahlen, 


\section{Evolutionizing Traditional Discipluines of Psychologiy}

Mills, Rick, \& Biblarz, 1999; S. L. Brown, Nesse, Vinokur, \& Smith, 2003). The role of the group is also central to N. B. Allen and Badcock's (2003) model, in which people carefully monitor what they can contribute to a group. People who realize they can contribute little retreat into depression that is hypothesized to prevent active expulsion from the group.

These approaches a re quite different from the prevalent view that depression is a brain disorder (Andreasen, 1984; Valenstein, 1998; Wolpert, 1999). The brain mechanisms that mediate mood certainly can go awry, but two questions need consideration. First, is low mood a useful response like cough or an abnormality unrelated to defenses like epileptic seizures? Second, do individual differences in vulnerability to depression arise mainly from primary brain differences or from brain changes mediated by social experience (C. W. Brown \& Harris, 1978; Monroe \& Simons, 1991)? These are not mutually exclusive alternatives, and most depression is best understood as the outcome of gene $x$ environment interactions (Caspi et al., 2003). Also, there are different routes to depression, some of which progress irrespective of environment, others of which arise from life circumstances, perhaps especially those involving pursuit of unreachable goals.

Other Emotional Disorters Anxiety and depression get all the attention, but every emotion is subject to at least two kinds of disorder: excesses or deficits. For instance, pathological jealousy is common, but few clinicians know why jealousy exists (Buss, Larsen, Westen, \& Semmelroth, 1992). Jealousy may arise for good reasons (Buss et al., 1999) or from delusions. Feelings of inadequacy make some men think that their partners might well prefer someone else and then that they do prefer someone else. Depression treat ment of ten relieves pathological jealousy (Stein, Hollander, \& Josephson, 1994). The syndrome of pathological lack of jealousy has yet to be described.

Comparable pathologies exist for every emotion. People are taken over by envy, love, suspicion, anger, awe, or rapture. Whether it is normal or abnormal depends on the situation. Recognizing the evolutionary origins and functions of emotions provides a framework for describing their disorders and the longsought scientific basis for distinguishing emotional disorders from emotions that are simply unwanted.

\section{Behavioral. Disorders}

Other disorders involve inability to control behavior. Most obvious are the addictions and other habits, but other problems of behavioral control range from eating disorders to violence.

Adtictions The human toll taken by addictions is magnified because their effects harm others as well as the addict. A whole issue of Addiction was devoted to evolutionary approaches (Hill \& Newlin, 2002), with suggestions about the adaptive significance of addiction (Sullivan \& Hagen, 2002), life history theory (Hill \& Chow, 2002), and the significance of fermentation (Dudley, 2002), among others. One of the most important evolutionary insights is simple, however. Learning is chemically mediated, so exogenous substances can directly stimulate reward mechanisms (Nesse, 1994; Nesse \& Berridge, 1997). The subjective sensations are pleasurable, and the associated reinforcement increases the frequency of drug- 
taking behavior. Aversive withdrawal symptoms become cues that stimulate further drug taking. Over time, the subjective pleasurable "liking" wanes, the withdrawal effects become more severe, and the habit strength of "wanting" increases, trapping the addict in a vicious cycle that may offer little pleasure, even as it consumes most of what is valuable in life.

Vulnerability to substance abuse results from our novel environment. The availahility of pure chemicals and clever routes of administration increase the rate of drug taking. Tobacco administered via the technological advance of cigarettes is the most widespread and harmful addiction, with alcohol a close second. The so-called hard drugs of abuse, such as amphetamine and cocaine, act even more directly on ascending dopamine tracts to establish addiction. Substance abuse is a universal human vulnerability to drugs that hijack reward mechanisms.

Why people differ in vulnerability is a fundamentally different question. Those who find it difficult to quit have different genes and more psychiatric symptoms (Pomerleau, 1997). The responsible genes are not "defective"; they caused no harm until the modern environment. Other vulnerability factors arise from environmental exposures, such as adverse circumstances that arouse aversive emotions that increase the reinforcing properties of drugs.

Habits Vulnerabilities to other habits have related evolutionary explanations. Gambling does not directly influence brain chemicals, but it is as potent for some people as heroin. Men without other options may take big risks to get a possible big reward, thus possibly explaining why poor people more of ten play the lottery. Gambling is a bigger problem for men than women, probably because over evolutionary history substantial resources brought increased mating success for men more than women. The tendency to persist in games of chance with known longterm negative payoffs, such as slot machines, reflects the distortions built into human decision making (Kahneman, Slovic, \& Tversky, 1982). Similarly, our evolved behavior regulation mechanisms lead to much other nonadaptive behavior in modern environments such as watching pornography, going to prostitutes, habitual web browsing, reading cheap novels, and engaging in private rituals, such as organizing and reorganizing a collection of stamps or coins.

Enting Disonders Half of Americans are now overweight, and a third are clinically obese. They spend billions on books and treatment, but nothing works very well. Vast amounts of research have tried to understand what is wrong with the heavy half. An evolutionary approach suggests a different question: Why are we all vulnerable to obesity? A simple answer is that our behavior regulation mechanisms were shaped in the very different environment of the African savannah where the penalty for eating too little was swift and fatal. Even when food was plentiful, obesity remained rare because choices were limited and getting food involved burning as many calories per day as a modern aerobics instructor (Eaton, Shostak, \& Konner, 1988).

Attempts to control weight by willpower lead to the other eating disorders, anorexia nervosa and bulimia. Adaptive explanations for anorexia as a variant mating strategy have been suggested (Surbey, 1987; Voland \& Voland, 1989). However, a simpler starting place is the ohservation that these disorders usually begin with strenuous diets. Such diets cause episodes of gorging, a hallmark of bulimia, but 
life-saving during famine. Gorging precipitates shame, feelings of lack of control, more intense fear of obesity, and new resolutions in a vicious cycle of escalating anorexia and bulimia. Eating disorders are also fostered by the intense mating competition in large social groups, augmented by media images that make real bodies seem inadequate. In light of the pervasiveness of mating competition, this makes perfect sense (Buss, 1988, 1994). As with other syndromes, vulnerability varies for many reasons.

Sexual Disorders Given its importance, you might think selection would have made sex foolproof. Instead, it exemplifies the vulnerabilities of a trait shaped by "multiple strong forces of selection (Troisi, 2003). For instance, men complain about premature orgasm while women complain about lack of orgasm. Why? Sex differences in brain mechanisms and differences in anatomic proximity to stimulation, yes, but these are proximate explanations. Why is the system so poorly designed for mutual satisfaction? Because selection does not shape mechanisms for mutual satisfaction. Women who had orgasms very quickly might well have had fewer children, as might men who dallied too long when interruption is likely. This is consistent with the observation that premature ejaculation is a problem mainly for men who are young or fearful.

Another dramatic sex difference is what it takes to initiate arousal. For many men, the answer is almost any sexual cue, anytime, anywhere (Symons, 1979). Pornography is a male pursuit; even magazines that display male bodies are bought mainly by men. Then there is the related problematic issue of why such a wide range of stimuli arouses men. We might suppose that selection would ensure that men want only potentially fertile partners, and most do. However, about $2 \%$ are exclusively homosexual, others are preoccupied with immature girls, and many have fantasy lives that involve domination or a fetish object. One explanation may be an error management theory for why men so systematically and optimistically distort the intentions of women (Haselton \& Buss, 2000). As for why so many individuals are exclusively homosexual, this remains unanswered, but not for want of theories (Ruse, 1988).

\section{BraIN DisORDERS}

Public relations campaigns, many supported by pharmaceutical companies, promote the view that mental disorders are brain disorders. This is necessarily true in the sense that brain changes mediate all emotion and behavior. However, slogans such as "depression is a brain disease" leave the mistaken impression that brain abnormalities are always the primary causes and that drugs are the only appropriate treatment. For some disorders such as schizophrenia, bipolar disorder, and autism, brain abnormalities are indeed the primary and usually sufficient cause. Other disorders, however, can occur in a brain that is perfectly normal or a brain that was normal until it experienced unnatural stimuli such as psychological trauma, drugs of abuse, severe dieting, or trying to work in a hostile bureaucracy. As noted already, an evolutionary perspective fosters a sophisticated assessment of the many factors that explain individual differences. Sone mental disorders are normal aversive emotions, others are dysregulated emotions, and some arise from 
factors only distantly related to the normal regulation of emotions, cognition, and behavior (Nesse, 1984). We turn to this last group to see what an evolutionary view can offer.

Schizophrenin Schizophrenia is the most serious common mental disorder. The symptoms have little to do with a "split mind" but instead reflect a systematic breakdown of perception, cognition, and emotion (Jablensky, Satorius, \& Emberg, 1992). While precursor symptoms can usually be detected, full-fledged psychosis most often begins just as the individual is trying to establish an individual identity in a social group. Many patients first feel excluded, then suspicious, then frankly paranoid with delusions that others are trying to harm them. Data showing strong influences of genetic factors and brain changes have convinced most researchers that the schizophrenias (there are multiple disorders) are best understood as the manifestations of brinin abnormalities. Some have suggested adaptive functions for symptoms of schizophrenia (J. S. Allen \& Sarich, 1988; Feicrman, 1982; Jarvik \& Chadwick, 1972), but little evidence supports this idea.

Delusions and hallucinations are not part of the routine experience of most humans. They are more like seizures and quite unlike adaptive defenses such as fever, cough, or anxiety. Schizophrenia prevalence rates are consistent at about $1 \%$ across cultures (Jablensky et al., 1992), undermining the idea that novelty explains psychosis. There is also strong evidence that schizophrenics have lower than average RS: .3 of average for males and .5 for females (Avila, Thaker, \& Adami, 2001; Pulver et al., 2004). The same data show no increased fitness of their close relatives, arguing against any selective benefit manifest in other individuals. It has been suggested that schizophrenia may persist "because it is the unattractive, low-fitness extreme of a highly variable mental trait that evolved as a fitness ('good genes') indicator through mutual mate choice" (Shaner, Miller, \& Mint $z, 20(4)$. Also, as mentioned alrady, infection has been implicated as an explanation for some cases of schizophrenia.

Trade-offs and the limits of natural selection may be important. Schizophrenia is not a universal human trait like the appendix; it is a rare syndrome. The evolutionary question is why natural sclection has not eliminated such fitness-reducing genetic variations. There are many possibilities. Selection might not be powerful enough to purge recurrent deleterious mutations from the gene pool. This is unlikely because the uniformity of incidence across cultures argues against a mutation occurring in the past 100,000 years, long enough to purge most seriously deleterious mutations. Another possibility is that so many genes are involved that selection can act on them only weakly. A related perspective is that normalizing selection can never shape a design parameter to an extremely narrow zone (Keller, in press). Even traits coded for by only a few genes are products of interactions with other genes and environmental factors that introduce substantial variation, leaving some individuals at maladaptive extremes.

A phylogenetic perspective offers related explanations. Human capacities for language and social cognition have advanced at a lightning pace in the past 100,000 years, almost certainly because they offer major fitness advantages (Humphrey, 1976). Such strong selection has costs that might well predispose to serious problems (Crow, 1997). Schizophrenia genes might also spread if they are linked to strongly beneficial genes (Burns, in press), but pleiotropic effects are 
more important. Cliff-edge effects offer a related possibility. For instance, racehorse breeding has resulted in longer and thinner leg bones that increase speed but are increasingly prone to fracture. If some mental characteristic gives increasing fitness up to a point where catastrophic failure becomes a problem, such cliffedge effects could account for the genetic patterns seen in schizophrenia and manic-depressive illness (Nosse, 2005).

The same lines of reasoning apply also to other severe mental diseases that also have an incidence of about 1 in 1(10)-autism in particular. Baron-Cohen (2002) has suggested that the manifestations of autism arc examples of a pathological extreme of cognitive styles that are typically male. This would help to explain the in predominance of males who get the disorder.

Other hypotheses also deserve consideration. For instance, it has been confirmed recently that the rates of schizophrenia increase dramatically for children who wore conceived when their fathers were over 40 (Byrne, Agerbo, Ewald, Eaton, \& Mortensen, 2003; Malaspina et al., 20(2). Cienes transmitted by the mother have divided only 24 times per generation, compared to 800 cell divisions for the DNA in sperm of older fathers, suggesting that many cases of schizophrenia arise from recurring new mutations. Among other implications, this falsifies the idea that women choose older men to get good genes.

Obsessive-Compulsize Disorder Obsessive-compulsive disorder (OCD) also shows substantial heritability and a $1 \%$ incidence. The condition is characterized by ritualistic repetitive behaviors and fears that some small oversight will lead to disaster. P'eople with OCD tend to have a smaller than normal caudate nucleus in the pons, and as already noted, some cases result from an autoimmune reaction to streptococcal infection (Swedo, Leonard, Garvey, \& Mittleman, 1996). It remains uncertiain if OCD is dysregulation of useful mechanisms or if it is something entirely separate (Rapoport \& Fiske, 1998).

\section{ATTENTION DISORDERS}

The cvolutionary origins of attention deficit hyperactivity disorder (ADHD) have been the focus for several articles suggesting possible functions (Baird, Stevenson, \& Williams, 2000; Brody, 2001; Jensen et al., 1997; Shelley-Tremblay \& Rosen, 1996) or that it is a facultative adaptation to certain environments (Jensen et al., 1997). The striking male bias of the sex ratio, over 5 to 1, gives hints that ADHD may simply be the extreme end of a continuum on which males tend to be higher than females, much akin to a recent suggestion about autism (Baron-Cohen, 20()2). In the ancestral environment, a tendency to move quickly to a new activity when current efforts are unproductive is a foraging strategy that may pay of more for hunting males than gathering females. As for the capacity to sit in one place indoors for hours under enforced contact with a boring book, that is so far from anything the natural cnvironment ever required, it is astounding that any of us can do it. The heritability of ADHD is high, and associations with candidate genes, notably DRD4, offer promising leads (Biederman \& Spencer, 1999). Because the 7R allele is common and in strong linkage disequilibrium, it may have experienced recent positive selection (Grady ct al., 20(03). 


\section{Relationship Difficulties}

The enormous importance of relationships in causing (and occasionally curing) mental disorders is so obvious that it is easy to neglect its significance. Mental health professionals of ten believe that normal relationships are warm, loving, and based on moral and emotional commitments. Would that it were so. By contrast, an evolutionary view of relationships emphasizes the costs and payoffs of different social strategies in terms of resources, reciprocal help, or inclusive fitness that can explain most tendencies to altruism (Fiske, 1992; Hinde, 1979; Hofer, 1984; Kirkpatrick, 1998). Evolutionary approaches have also emphasized the prevalence of deceptive strategies and self-deception (Krebs \& Dawkins, 1984; Lockard \& Paulhus, 1988; Rue, 1994; Slavin \& Kriegman, 1992; Trivers, 2000), thus opening a little-traveled avenue between EP and psychoanalysis. Other chapters in this Handbok show how selection shaped the mechanisms that mediate relationships, knowledge crucial to understanding how relationships go wrong.

Sexual relationships and strategies have been a focus for EP, and the results of that research are ripe for application to clinical situations (Buss, 1994; Buss \& Malamuth, 1996). For species with mating systems similar to those of humins, careful choice of partners benefits females more than males, and efforts to get many matings benefit females more than males. As a result, sexual jealousy is more intense for males, and opposition to mates griving resources to others tends to be greater for women (Buss \& Schmitt, 1993). Moreover, as every grandmother knows, the facts of pregnancy and male jealousy make short-term matings less costly and predictably more common in males.

Child Abuse Child abuse has been a major focus for mental health prevention and treatment. Understanding the evolutionary origins and functions of attachment has helped to explain why most parents do not abuse their children despite provocations (Bowlby, 1984). An evolutionary perspective motivated two behavioral ecologists to ask the now-obvious question: Is child abuse more common in $\mathrm{families}$ with a stepparent? Their astounding result is that death at the hands of parents is 80 times more common if there is a stepparent in the house. (Daly \& Wilson, 1988). This finding is commonly presented in a context franed by the tendency of males in many species to kill all unweaned infants shortly after they take over a female mating group (Hrcly, 1977). However, the mating pattern of humans does not routinely involve males fighting to take over a harem with multiple fernales who are nursing infants, so the analogy is incorrect. Instead, the mechanisms that protect babies in families with two related parents seem more prone to fail in reconstituted families (Gelles \& Lancaster, 1987).

\section{CONCLUSIONS}

All it would take is discovery of a single cure. Even discovery of the definitive cause for a single illness would do. If EP leads directly to such a treatment or discovery, it will grow quickly. Is this a legitimate hope? Superficially, the answer is no. Instead of explanations for why some individuals get sick and others do not, EP explains why mechanisms are the way they are and why natural selection has not eliminated the genetic variations that result in disease for some. Its most 
profound contribution is a solid framework for understanding how behaviors are regulated to accomplish the many conflicting tasks of life, from getting food and surviving, to finding mates and protecting children. Instead of viewing one kind of life as normal and others as deviations, it sees the inherent conflicts in relationships, the struggles that go on in groups, and the dilemmas every person faces to allocate efforts among a host of competing needs. Far from providing a rigid and cold perspective, an evolutionary view fosters deeper empathy for the challenges we all face and deeper amazement that so many people are able to find loving relationships, meaningful work, and a way to juggle a bevy of responsibilities with good humor and even joy.

Does this presage a new kind of psychotherapy? There certainly are major implications for how to do psychotherapy (Cilbert \& Bailey, 2000) and psychoanalysis (Slavin \& Kriegman, 1992), but they do not constitute a new kind of therapy competing with hundreds of others. Every kind of therapy should make use of evolutionary principles. The juggernaut now is psychopharmacology, soon to be united with genetics to yield new methods for manipulating emotions and behavior that we cannot yet imagine. In the near future, they should yield more effective treatments for schizophrenia and manic-depressive illness. Evolutionary investigations can assist in these quests by defining phenotypes and identifying evolved behavior regulation mechanism. These same genetic and pharmacologic technologies will make it easier to manipulate normal as well as abnormal emotions. Their focus exclusively on proximate perspectives holds the risk that we will block negative emotions and promote positive ones even before we grasp why they exist at all. Cautionary tales abound. For instance, when cortisol was first discovered, it was used to relieve the symptoms of all kinds of inflammation. It worked like a miracle and patients felt better, so why not? In a few years, however, the serious consequences of blocking these normal reactions became clear.

An evolutionary view of mental disorders does not mean accepting the pains and difficulties of the human condition. Many can be prevented or eliminated safely, but only when we better understand the functions of negative emotions. Furthermore, a signal detection analysis of their regulation suggests that in many situations they are about as useful as pain after surgery. It is even conceivable that the personality tendencies that foster envy and bitter competition, to say nothing of violence, might well be modifiable. None of this will be simple, however. Moreover, every such new major capacity for intervention will be far safer and more sensible if developed in a sophisticated evolutionary context.

\section{REFERENCES}

Alexander, R. D. (1974). The evolution of social behavior. Anmual Renied! of Systematics, 5, 325-383.

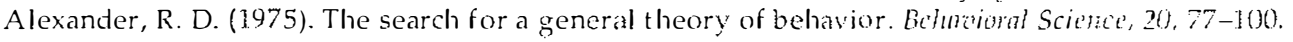

Allen, J. S., \& Sarich, V. M. (1988). Schizophrenia in an evolutionary perspective. Ptrspetiot's in Biology and Meticinc, 32, 132-15.3.

Allen, N. B., \& Badcock, P. B. T. (2003). The social risk hypothesis of depressed mood: Evolutionary, psychosocial and neurobiological perspectives. Psychological Bullitin, 129, 887-913.

American Psychiatric Association. (1994). Diagnostic and statistical mommal of montal diserders: DSMIV (4th ed.). Washington, DC: Author.

Andreasen, N. C. (1984). The broken brain: The biological rezolution in psychiatr. New York: Hanper \& Row.

Archer, J. (1999). The nature of grief. New York: Oxford University freess. 
Avila, M., Thaker, G., \& Adami, H. (2001). Genetic epidemiology and schizophrenia: A study of reproductive fitness. Schizoplrenia Res, 47, 233-241.

Badcock, C. (1988). Essentinl Fremd. Oxford, England: Basil Blackwell.

Badcock, C. (2000). Eiolutionury psychology: A critical introduction. Cambridge, UK: Blackwell.

Baird, J., Stevenson, J. C., \& Williams, D. C. (2000). The evolution of ADHD: A disorder of communication? (liarterly Reviea of Biology, 75, 17-35.

Barkow, I. (1989). Darwin, sex, and status: Biological approaches to mind and culture. Toronto: University of Toronto Press.

Barkow, I., Cosmides, L., \& Tooby, J. (Eds.). (1992). The ad apted mind. New York: Oxford University Press.

Barlow, O. H. (988). Anxicty and its disorders. New York: Guilford Press.

Baron-Cohcin, S. (19)5). Nindbindne'ss: An essay on autism and the theory of mind (Vols. 37-46). Cambridise, MA: MIT press.

Baron-Cohen, S. (Ed.). (1997), The malatapted mind. East Sussex: Psychology Press, Erlbaum.

Baron-Cohen. S. (2002). The extreme male brain theory of autism. Trends in Cognitive Science, 6 , $248-254$

Barrett, L., Dunbar, R. 1. M., \& Lycett, J. (2002). Human ewdutionary psychology. Basingstoke: Palgrave.

Bateson, P. P. G., \& Martin., P. R. (2000). Design for a life: How beharior and personality deadop. New York: Simon \& Schuster.

Belsky, J. (1999). Nodern evolutionary theory and patterns of attachment. In J. Cassidy \& P. R. Shaver (lids.). Hanthook of altachment: Theory, research, and climical applicatious (pp. 141-161). New rork: Cruilford Press.

Bel:ky, J., Steinberg, J., \& Draper, P. (1991). Childhood experience, interpersonal development, and repruductive: stratesy: An evolutionary theory of socialization. Child Deatopment, 62, 647-670.

Bibring, E. (1953). The mechanisms of depression. In P. Greenacre (Ed.), Affective disorders (pp. 13-it8). New York: International Universities Press.

Biederman, J., \& spencer, T. (1999). Attention-deficit/hyperactivity disorder (ADHD) as a noradrenereric disorder. Biological Pagchiatry, 46, 1234-1242.

Bowlby, J. (1969). Attachmenf tut loss: Vol. 1. Attachment. New York: Basic Books. "

Bowlty 1. (1984). Violence in the family as a disorder of the attachment and caregiving systems. Ancrical foumal of Pstychoululysis, 44, 9-27, 29-31.

Bresfau, N., Davis, G. C., \& Andreski, P. (1995). Risk factors for PTSD-related traumatic events: A prospective analysis. Amorican foumal of Psychiatry, 152, 529-535.

Brickmian, P. (1987). Commitmemt, conflict, and caring. Englewood Cliffs, NI: Prentice-Hall.

Brody, 1. F. (2001). Fvolutionary recasting: ADHD, mania and its variants. Journal of Affective Disorder: $55,197-215$.

Brown, A. S., Begry, M. D., Cravenstein, S., Schaefer, C. A., Wyatt, R. J., Bresnahan, M., ct al. (2004). Serologic evidence of prenatal influenza in the etiology of schizophrenia. Archizes of General Psuchintry, 61, 774 780 .

Brown, C. W., \& Harris, T. O. (1978). Socintorigins of depression. New York: Free Press.

Brown, C. W., Harris, T. O., \& Hepworth, C. (1995). Loss, humiliation and entrapment anzong women developing depression: A patient and non-patient comparison. Psychological Medicine, 25, 7-21.

Brown, R., Dahlen, E., Mills, C., Rick, 1!., \& Biblarz, A. (1999). Evaluation of an evolutionary model of self-preservation and self-destruction. Sucide and life-Threatening Behazior, 29, 58-71.

Brown, S. L., Nesse, R. M., Vinokur. A. D., \& Smith, D. M. (2003). Providing social support may be more beneficial than receiving it: Results from a prospective study of mortality. Psychological Sciche, $1+3,30 \ldots 327$.

Burns, J. K. (in press). An evolutionary theory of schizophrenia: Cortical connectivity, mctarepresentation and the social brain. Brain and Behavioural Sciences.

Burton, R. (1931). The anatomy of melancholy. London: Routledge and Sons. (Original work published $162+)$

Buss, D. M. ( 19,58$)$. The evolution of human intrasexual competition: Tactics of mate attraction. Jour-

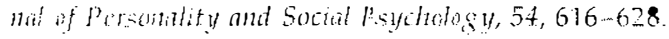

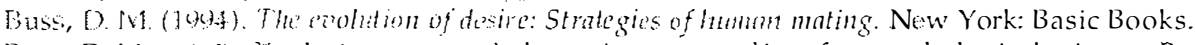

Buss, D. M. (1945). Fvolutionary psychology: A new paradigm for psychological science. Psychologi(iil liminity: $5,1-30$ ).

Buss, D. M. (2000). The evolution of happiness. American Psychologist, 55, 15-23. 


\section{Evolutionizing; Traditional Disciplines or Psycliology}

Buss, D. M. (2003). The evolution of desire: Strategies of luman mating (Rev. ed.). New York: Basic Books.

Buss, D. M. (2004). Evolutionary psychology: The ne'te science of the mind (2nd ed.). Boston: Allyn \& Bacon.

Buss, D. M., Larsen, R. J., Westen, D., \& Semmelroth, J. (1992). Sex differences in jealousy: Evolution, physiology, and psychology. Psychological Science, 3, 251-255.

Buss, D. M., \& Malamuth, N. M. (1996). Sex, power, conflict: Evolutionan! and feminist perspection's. New York: Oxjord University Press.

Buss, D. M., \& Schmitt, D. P. (199.3). Sexual strategies theory: An evolutionary perspective on human mating. Piychological Revicel, 700, 204-232.

Buss, D. M., Shackelford, T. K., Kirkpatrick, L. A., Choe, I., Haseguwa, M., Hasegrwa, T., et al. (1999). Jealousy and beliefs about infidelity: Tests of competing hypotheses in the United States, Korca, and Japan. Personal Relationships, 6, $125 \ldots 150$.

Byrne, M., Agerbo, E., Ewald, M., Eaton, W. W., \& Mortensen, P. B. (2003). Parential age amd risk of schizophrenia: A case-control study. Archices of General Psychiatry, 60), 673-678.

Carver, C. S., \& Scheier, M. F. (1990). Origins and functions of positive and negative affect: A control-process viow. Psiycholougical Revilew, 97, 19-35.

Carver, C. S., \& Scheier, M. F. (1998). On the self-recrulation of tehowior. New York: Cambridge University Press.

Caspi, A., Sugden, K., Moffitt, T. E., Taylor, A., Craig, I. W., Harrington, I-1, et al. (20)3). Influence of life stress on depression: Moderation by a polymorphism in the 5-HTT gene. Science, 301 , $386-389$.

Chisholm, J. (1996). The evolutionary ecology of human attachment organization. Humul Nafure, 7, $1-38$.

Chisholm, J. (1999). Death, hope and sex: Steps to an coolutiouary coology of mind and morulity. New York: Cambridge Lniversity Press.

Cosmides, L., \& Tooby, 1. (1999). Towards an evolutionary taxonomy of treatable conditions. fourmal of Almormal Psychology, 108, 453-464.

Crawford, C., Smith, M., \& Krebs, D. (Eds.). (1987). Sociobiology and piychologry: heras, issues and applications. Hillsdale, NJ: Erlbaum.

Cronin, H. (1991). The ant and the penock: All rus san and sexual selation from Darain to today. New York: Cambridge University Press.

Cross-National Collaborative Group. (1992). The changing rate of major depression: Cross-national comparisons. foumal of the American Medical Association, 268, 3098 3105.

Crow, T. J. (1997). Is schizophrenia the price that Homo sapiens fays for language? Schizophrenia Research, 28, 127-141.

Daly, M., \& Wilson, M. (1983). Sex, ceolution, and belabior (2nd ed.). Boston: Willard Grant Press.

Daly, M., \& Wilson, M. (1933). Evolutionary social psycholory and family homicide. Science, 242, $519-524$

deCatanzaro, D. (1980). Human suicide: A biological perspective. Behaziomil and brain Sciences, 3.

Draper, P., \& Harpending, H. (19832). Father absence and reproductive strategy: An evolutionary perspective. Jotmmal of Anthropological Re'search, 38, 255-273.

Dudley, R. (2002). Fermenting fruit and the historical ecology of ethanol ingestion: Is atcoholism in modern humans an evolutionary hangover? Adtiction, 97, 387 . 3353.

Eaton, S. B., Shostak, M., \& Konner, M. (1988). The Paleolithic prescription. New York: Harper \& Row.

Eaton, 5. B., Strassmann, B. I., Nesse, R. M., Neel, J. V., Evald, 1. W., Williams, G. C., et al. (20)2). Evolutionary health promotion. Prenentive Medicine, 34, 109-118.

Ekman, P. (1992). An argument for basic emotions. Cognition and Fmotion, 6, 169 200.

Emnzons, R. A., \& King, L. A. (1988). Conflict among personal strivings: Im mediate and lon $y$-term implications for psychological and physical well-being. fommal of Porsomality and Secial Psychot$0, y, 54,104(0) 1048$.

Ericson, M. T. (1993). Rethinking Oedipus: An evolutionary perspective on incest averidance. American loumal of Psychiatry, 150,411.

Essex, M., Klein, M., Eunsuk, C., \& Kialin, N. (2002). Maternal stress begrinning in infancy maly sen-

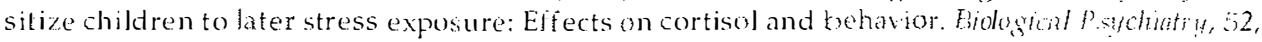
$776-786$.

Ewald, P. (1994). Eablution of infections disetwe. New York: Oxford Liniversity Press. 
Ewald, P. (2000). Plague time: Howe stealth infections canse cancers, heart disense, and other deadly aitments. New York: Free Press.

Fabrega, H. (2002). Origins of psychopathology: The phylogenetic and cultural basis of mental illness. New Brunswick, N!: Rutgers University Press.

Fehr, E., \& Fischbacher, U. (20)3). The nature of human altruism. Nature, 425, 785-791.

Feierman, I. R. (198;2). Nocturnalism: An ethological theory of schizophrenia. Medical Hypothe'se's, $9,455-479$.

Fessler, D. M. (in press). The Strategy of affect: Emotions in human cooperation. In P. Hammerstein (Ed.), Gonetic and cultural eadution of coopration: Dahlom Workshop Report (Vol. 29). Cambridge, MA: MIT Press.

Fiske, A. P. (1992). The four elementary forms of sociality: Framework for a unified theory of social relations. Psycholonical Review, 99, 689-723.

Foa, E. B., Steketee, G. S., \& Ozarow, B. J. (1985). Behavior therapy with obsessive-compulsives. In M. Mavisiakialian, S. M. Turner, \& L. Lichelson (Eds.), Obsessine-tompulsine disorder: Psychologrical and phambolocical trentheml (pp. 49-129). New York: Plenum Press.

Frank, R. H. (1988). Passions at ithin renson: The stratequic role of the emotions. New York: Norton.

Frank, R. H. (1999). Luxury feoer: Why money fails to satisfy in an cra of excess. New York: Free Press.

Fredrickson, B. L. (1998). What good are positive omotions? Reorice of General Psychology: Specinl issule: Neäb Directions in Resentch on Enotion, 2, 30()-319.

French, J. A., Kamil, A. C., \& Leger, D. W. (Eds.). (2000). Evolutionary psychology and motiontion (Vol. 48). Lincoln: University of Nebraska Press.

Craulin, S. I. C., \& McBurney, D. H. (20)I). Psychology: An easolutionary approach. Upper Saddle River, NJ: Prentice-Hall.

Geary, D. C. (1998). Mole, female: The evolution of human sex differences (1st ed.). Washington, DC: American l'sychological Association.

Geary, D. C, \& Bjorklund, D. F. (20)(0). Evolutionary developmental psychology. Child Derolopment, $7 i, 57 \cdots 65$.

Colles, R. J., \& Lancaster, J. B. (1987). Child abuse and neylect: Biosocinl dimentions. New York: Aldine De Crutyter.

Cilbert, P. (1992). Depression: The evolution of powerlessmess. New York: Cuilford Press.

Gilbert, P. (2001). Evolution and social anxiety: The role of attraction, social competition, and social hierarihies. Psychiatric Climics of North America, 24, 723-751.

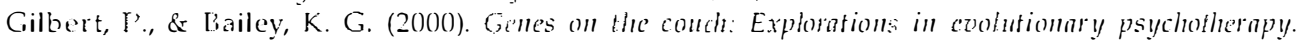
I'hiladelphia: Taylor \& Francis.

Gilbert, P., Price, I., \& Allen, S. (1995). Social comparison, social attractiveness and evolution: How might they be related? New lders in Psychology, 13, 149-165.

Gintis, H. (200(0). Strong reciprocity and human sociality. fourmal of Theoretical Biology, 206, $169-179$.

Clanti, K., \& Pearce, I. (1989). Exiles from Eden. New York: Norton.

Craty, D. L., Chi, H. C., Ding, Y. C., Smith, M., Wang, E., Schuck, S., et al. (2003). High prevalence of rare dopamine receptor D4 alleles in children diagnosed with attention-deficit hyperactivity disorder. Molcular Fsychiatry. 8, 536-545.

Gut, E. (1989). Productien and mimprodutioe depression. New York: Basic Books.

Hagen, E. H. (2002). Depression as bargaining: The cose postpartum. Exolution and Humm Eehavior, $2.3,323-336$.

Hall, B. K. (1998). Eivhutionary developmental biology (2nd ed.). London; New York: Chapman \& Hall.

Hamburg, B). A., Hamburg, B. A., \& Barchas, J. D. (1975). Anger and depression in perspective of behavional biology. In L. Levi (Ed.), Emotions: Thirir parameters ant mensmement (pp. 235-278). New York: Riven Press.

Haselton, M. C., \& Buss, D. M. (20)(0). Error managenent theory: A new perspective on biases in

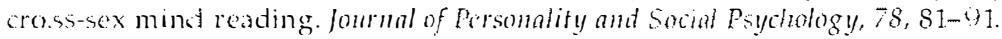

Henrich, .., \& Cil-White, F. (2001). The evolution of prestige. Eudution and Human Behmaior, 22, $165-196$.

Hill, E. M., \& (hew, K. (2())2). Life-history theory and risky drinking. Addiction, 97, 401-413.

Hili, E. M. \& Newlin, D. B. (20)2). Evolutionary approaches to addiction. Addiction, $97,375 \cdots 379$.

Hinde, R. A. (1979). Toülords understanding relationships. fondon: Academic Press.

Hofer, M. A. (1984). Relationships as regulators: A psychobiologic perspective on bereavement. Pswhommiatic Meticine, $46,183-197$. 


\section{Evolutionizing Traditional Disciplaines of Psychology}

Horrobin, D. F. (1998). Schizophrenia: The illness that made us human. Medicol Hypotheses, $269-288$.

Horwitz, A. V. (2002). Creinfing mental illness. Chicigo: University of Chicago Press.

Hrdy, S. B. (1977). Infanticide as a primate reproductive strategy. Anerican Scientist, 65, 40-49.

Hrdy, S. B. (1999). Mother mature: A history of mothers, infonts, and matural selection (1st ed.). New York: Pantheon Books.

Humphrey, N. K. (1976). The social function of intellect. In P. C. Bateson \& R. A. Hinde (Eds.), Growing points in etholosy (Pp. 303-318). London: Cambridge University Press.

Institute of Medicine. (1987). Comses and consequences of alcohol problems: An agenda for research. Washington, DC: National Academy Press.

Jablensky, A., Satorius, N., E Emberg, C. (1992). Schizophrenia: Manifestations, incidence and course in different cultures. A World Health Organization ten country study. Psychological Med-

- icinc Moincigriph Supplimest, 20, 1-97.

Janoff-Bulmian, R., \& Brickman, P. (1982). Expectations and what people learn from failure. In N. T. Feather (Ed.), Expretotions and action. Hillsdale, NJ: Erlbam.

Jarvik, L. F. \& Chadwick, S. B. (19;2). Schizophrenia and survival. In ML. Himmer, K. Salzinger, \& S. Sutton (Eds.), Psichopatholo,y. New York: Wiley.

Jensen, P. S., Mrazek, D., Knapp, P. K., Steinberg, L., Pfeffer, C., Schowalter, J, et al. (1997). Evolution and revolution in child psychiatry: ADHD as a disorder of adaptation. fourmal of the Ameriim Acodomy of Child and Adolescent Fsychiatiy, 36, 1672-3679.

Kahneman, D. Slovic, P., e Tversky, A. (1982). Judsment ander uncertainly: Heuristics and biases. New York: Cambridgo Universily Press.

Kat\%, L. (2000). Eahlutionary origins of morality: Cross disciplinary perspectioes. Devon: Imprint scademic.

Keller, M. (in press). Evolutionary explinations of schizophrenia must ultimately explain the genes that predispose to it. Boflumoral and brain Sciences.

Kendter, K. S., Hettema, J. M., Bulera, F., Gardner, C. O., \& I'rescott, C. A. (2003). Life event dimensions of loss, humiliation, entrapment, and danger in the prediction of onsets of major depression and gencralized anxicty. Archio's of Gemeral Psychintry, 60, 789-796.

Kendler, K. S., Kuhn, J., \& Prescott, C. A. (2004). The interrolationship of neuroticism, sex, and stressful life exents in the prediction of episodes of major depression. American fournal of PsyHiat $161,031+636$.

Kessler, R., \& Ustun, T. (2000). The World Health Organization World Mental Health 2000 Initiative. Hospital Momiganent latermational, 195-196.

Kirkpatrick, L. A. (1998). Evolution, pair bonding, and reproductive strategies: A reconceptualization of adult athohment. In W. S. Rholes (Ed.). Athachnent theory and close relationships (pp. 35.3-393). Now York: Guilford Press.

Klinger, E. (1975). Consequences of commitment to and disengagement from incentives. Psychological Revicie, 82, 1-25.

Krebs, I., \& Davies, N. B. (Eds.). (1984). Bcharioural ecology: An evolutionary approach (2nd ed.). Suncierlind, MA: Sinaver.

Krebs, 1., \& Dawkins, R. (1984). Animal signals: Mind-reading and manipulation. In J. R. Krebs \& N. B. Davies (Eds.), Beharioral cology: An evolutionary approach (pp. 380-402). Sunderland, :MA: Sinaluer.

Kruger, D. \& Nesse, R. (2004). Sexual selection and the Male: Female Mortality Ratio. Eirolutionary Peycholo, $2,60-85$.

Kumugi, H., Nanko, S., Takei, N., Saito, K., Hayashi, N., \& Kazamatsuri, H. (1995). Schizophrenia following in utero exposure to the 1957 infhenza epidemics in Japan. American Jourmal of Psychialry $152,450 \cdots 452$.

Leary, M. R., \& Kowalski, M. (1995). Social muxicty. New York: Guilford Press.

Ledgerwood, L.. Ewald, P., \& Cochran, G. (200.3). Genes, germs, and schizophrenia: An evolutionary perspective. Perspections in Biology and Medicine, 46, 317-348.

Little, B. R. (1996). Personality and motivation: Personal action and the conative evolution. In L. A. pervin (Ed.), Hand bot of fersonality: Theory mut research (2nd ed, Pp. xiii, 738). New York: Guilford Press

Lockard, I. 5., \& Paulhus, D. L. (Eds.). (1988). Selfodecoption: An aibutiae mechanism? Engehwood Cliffes, N): Prontice...hall.

Low, B. S. (2000). Why sex matters. Princeton, NJ: Princeton University Press. 
Malaspina, D., Corcoran, C., Fahim, C., Berman, A., Harkavy-Friedman, J., Yale, S., et al. (2()()2). Paternal age and sporadic schizophrenia: Evidence for de novo mutations. Anerican foumal of Clinical Cienetics, 114, 299-303.

Marks, I. M. (1987). Fears, phobirs, and rituals. New York: Oxford University Press.

Marks, I. M. \& Nesse, R. M. (1994). Fearr and fitness: An evolutionary analy'sis of anxiety disorders. Ethology and Socioliology, 16, 247-261.

Marks, I. M., \& Tobena, A. (1990). Learning and unlearning fear: A clinical and evolutionary perspective. Netriscience and Eiwbehariomal Rewiezs, 14, 365-384.

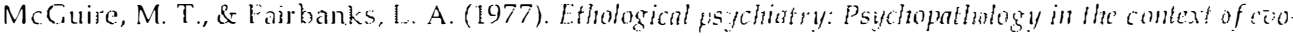
lutionary biology. New York: Grune and Stratton.

MeGuire, M. T., \& Troisi, A. (1998). Daramian psydiatry. Cambridge, MA: Harvard University Press.

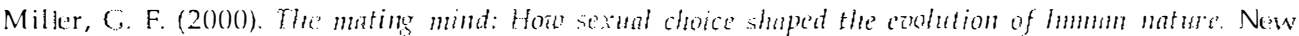
York: Doublediay.

Mineka, S., Keir, R, \& Price, V. (1980)). Fear of snakes in wild-and laboratory-reared rhesus monkeys (Macaca mulatta). Animal l, warnine and Behation, 8.653-66.3.

Momroe, S. M., \& Simons, A. D. (1991). Diathesis-stress theories in the context of life stress rosearch: Implications for the depressive disorders. Psylhological Bulletin, 110, 406-425.

Murphy, D. \& Stich, S. (2.)(0)). Darwin in the madhouse: Evolutionary psychology and the classilication of mental disorders. In P. Carrulhers \& A. Chamberlain (Eds.), Enolubion and the hannh mind: Moduterity, hongmere and mela-tognition (pp. 62 92). Cambridge, Engtame: Cambridge Lniversity Press.

Murphy. I. M., Laind, N. M., Monson, R. R., Sobol, A. M., \& Leighton, A. H. (2000). A 40-year perspective on the prevalence of depression: The Stirling County Study. Arhires of General Paydhit. triv, 57, 209-215.

Nesse, R. M. (1984). An evolutionary perspective on psychiatry. Comprehinsioe Psylintry, 25, $575-580$.

Nesse, R. M. (1987). An evolutionary perspective on panic disorder and aroraphobia. Etholocry and Socioliology, $8,573-583$.

Nesse, R. M. (199()3). Evolutionary explanations of emotions. Human Nature, 1, 261-289.

Nesse, R. M. (1990b). The evolutionary functions of repression and the ego defenses. foumal of the American Acatemy of P.sychomalysis, 18, 260-285.

Nesse. R. M. (199 a). What good is feeling bad? Sciences (November/Decemberi, 30 )-37.

Nesse, R. M. (1991b). What is mood for? Psycoloquy, 2, 9.

Nesse, R. M. (1947). An evolutionary perspective on substance abuse. Ethology and Socfobiology. 15, $339-348$

Nesse?, R. M. (200(0)). Is depression an adaptation? Archines of Genernl Psychintry, 57, 14-20.

Nesse, R. M. (2001a). Eoolution and the onpacity for commitment. New York: Russell Sacre Foundation.

Nesse, R. M. (20)16). On the difficulty of defining disease: A Darwinian prespective. Metical Health Care and Philosophy, $4,37 \ldots 46$.

Nesse, R. M. (2004). Natural selection and the elusiveness of happiness. Philosuphicint transantions of the Rounl Socity of Lonton. Series B, Biolegical Scichic's, 359, 1333-1347.

Nesse, R. M. (2005). Natural selection and the regulation of defenses: A Signal Detection Analysis of the Smoke Detector Principle. Evolution and Human Behavior, $26,88-1(15$.

Nesse, R. M. \& Berridge, K. C. (1997). Psychoactive drug use in evolutionary ferspective. Science, $278,63-66$.

Nesse, R. M., \& Williams, G. C. (1994). Why we wet sick: The new science of Darainian medicine. New York: Vintage.

Netlle, D. (2()(). f). Evolutionary origins of depression: A review and reformulation. fomm of Affecthe Divorters, $81,91-102$

Phillips, K. A., Fust, M. B., \& Pincus, H. A. (20):3), Adzancing, DSM: dilemmas in psychiatrit dingnosis. Washington, DC: American Psychiatric Association.

Pitchford, 1. (2001). Evolutionary developmental psichopalhology. Humm Nature Rericio. Available from htlp: // human nature.com/darwin/edp.html.

Pitman, R. K. (1989). Post-traumatic stress disotder, hormones, and memory. Biolegical Psycliatry. $26,221-223$

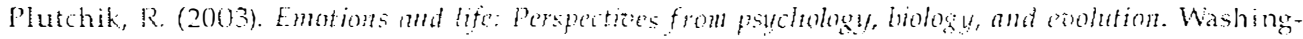
ton, DC: American Pstchological Association. 


\section{Evolutionizing Traditional Disciplines of Psychology}

Pomerleau, C. S. (1997). Cofactors for smoking and evolutionary psychobiology. Adtiction, 92, 397-408.

Poulton, R., Davies, S., Menzies, R. G., Langley, J. D., \& Silva, P. A. (1998). Evidence for a nonassociative model of the acquisition of a fear of heights. Belmaioural Re'search and Therapy, 36 , $537-544$.

Poulton, R., \& Menzies, R. G. (2002). Non-associative ferr acquisition: A review of the evidence from retrospective and longitudinal research. Bontoural Re'search and Therapy, 40, 127-149.

Pulver, A. E., McGrath, J. A., Liang, K. Y., Lasseter, V. K., Nestadt, G., \& Wolyniec, P. S. (2004). An indirect test of the new mutation hypothesis associating advanced paternal age with the etiology of schizophrenia. American Journal of Clinical Genctics, 124 B. 6-9.

Quirk, G.J. (2002). Memory for extinction of conditioned fear is long-lasting and persists following spontaneous recovery. Learn Min, 9, 402-407.

Rapoport, J. L., \& Fiske, A. (1998). The new biology of obsessive-compulsive disorder: In plications for evolutionary psychology. Perspectives in Biology and Medicine, 41, 159-175.

Richards, R. L., Kinner, D. K., Lunde, I., \& Benet, M. (1988). Creativity in manic-depressives, cyclothymes and their normal first-degree relatives: A preliminary report. foumal of Abnormal Psyclology, 97, 281-288.

Ridley, M. (2003). Nature zia murhure: Genes, experience, and what makes us lumman. New York: HarperCollins.

Rue, L. D. (1994). By the grace of guile: The role of deception in natural history and luman affairs. New York: Oxford University Press.

Ruse, M. (1988). Homosexuality: A plinlosoplical inquiry. New York: Blackwell.

Rutter, M., \& Rutter, M. (1993). Developing minds: Challenge and continuity across the life span. New York: Basic Books.

Shaner, A., Miller, G., \& Mintz, J. (2004). Schizophrenia as one extreme of a sexually selected fitness indicator. Schizoplurenia Research, 70, 101-109.

Shelley-Tremblay, J. F., \& Rosen, L. A. (1996). Attention deficit hyperactivity disorder: An evolutionary perspective. Journal of Genetics and Psychology, 157, 443-453.

Slavin, M. O., \& Kriegman, D. (1990). Toward a new paradigm for psychoanalysis: An evolutionary biological perspective on the classical-relational dialectic. Psychoanalytic Psychology, 7 [Suppl.], $5-31$.

Slavin, M. O., \& Kriegman, D. (1992). The adaptive design of the humm psyche: Psychoanalysis, evolutionary biology, and the therapentic process. New York: Guilford Press.

Sloman, L., I'rice, ]., Gilbert, P., \& Gardner, R. (1994). Adaptive function of depression: Psychotherapeutic implications. American Journal of Psychotherapy, 48, 1-16.

Smith, E. A., \& Winterhalder, B. (Ects.). (1992). Evolutionary ecology and human behanior. New York: Aldine de Gruyter.

Smith, M. (1986). Genetics of human alcohol and aldehyde dehydrogenases. Adrances in Human Genetics, $15,2 \cdot 19-290$.

Stearns, S. C. (1992). The cvolution of life historie's. Oxford England; New York: Oxford University Press.

Stein, D. J., \& Bouwer, C. (1997). A neuro-evolutionary approach to the anxiety disorders. Journal of Anxiety Disorters, 11, 409-429.

Stein, D. J., Hollander, E., \& Josephson, S. C. (1994). Serotonin reuptake blockers for the treatment of obsessional jealousy. Jourmal of Clinical Psychiatry, 55, 30-33.

Sterelny, K., \& Griffiths, P. E. (1999). Sex and death: An introduction to philosoplyy of biology. Chicago: University of Chicago Press.

Stevens, A., \& Price, J. (1996). Evolutionary psychiatry: A new beginming. London: Routledge.

Sullivan, R. J., \& Hagèn, E. H. (2002). Psychotropic substänce-seeking: Evolutionary pathology or adaptation? Actdiction, 97, 389-400.

Sulloway, F. J. (1985). Frelut, biologist of the mint. New York: Basic Books.

Surbey, M. K. (1987). Anorexia nervosa, amenorrhea, and adaptation. Etlology and Sociobiology, 8 , $47-61$.

Surbey, M. K. (1990). Family composition, stress, and the timing of human menarche. In T. E. Zeigler \& F. B. Bercovitch (Eds.), Socioendocrinology of primate reproduction (pp. 11-32). New York: Wiley.

Swedo, S., Leonard, H., Garvey, M. A., \& Mittleman, B. B. (1996). PANDAS: Pediatric Autoimmune Neuropsychiatric Disorders Associated with Strep-ls this a new species of childhood-onset obsessive-compulsive disorder and Tourette's syndrome? European Neuropsychopharmaculogy, 6, S4. 
Swedo, S., Leoncird, H., \& Kiessling, L. (1994). Speculations on antineuronal antibody-mediated neuropsychiatric disorders of childhood. Pediatrics, 93, 323-326.

Symons, D. (1979). The conlutiou of human sexuality. New York: Oxford University Press.

Teicher, M. H., Andersen, S. L., Polcari, A., Anderson, C. M., Navalta, C. P., \& Kim, D. M. (2003). The neurobiological consequences of early stress and childhood maltreatment. Neuroscience and Biobehnoional Revicies, 27, 33-44.

Tooby, J., \& Cosmides, L. (1990). The past explains the present: Emotional adaptations and the structure of ancestral environments. Ethology and Sociobiology, 11, 375-424.

Trivers, R. (1974). Parent-offspring conflict. American Zoologist, 14, 249-264.

Trivers, R. (1976). Forward. In R. Dawkins (Ed.), The selfish gene. New York: Oxford University Press.

Trivers, R. (2000). The elements of a scientific theory of self-deception. Annals of the New York Academy of Scismess $907,114-131$.

Troisi, A. (2003). Sexual disorders in the context of Darwinian psychiatry. Journal of Endortinological lmestigntion, 26, 54-.57.

Troisi, A., \& McCuire, M. (2002). Darwinian psychiatry and the concept of mental disorder. Nelroeintocrinology Letters, 23, [Suppl] (4), 31-38.

Valenstion, E. S. (1998). Blaming the brain: The truth about drugs and mental health. New York: Free Press.

Veblex, T. (1899). The thenry of the leisure class: An economic study in the evolution of institutions. New York: Macmillan

Voland, E. \& Voland, R. (1989). Evolutionary biology and psychiatry: The case of anorexia nervosa.

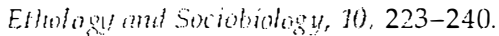

Wakefield, I. C. (1992). Disorder as harmful dysfunction: A conceptual critique of DSM-HII-R's definition of mental disorder. Psychological Review, 99, 2332-247.

Watson, P. I, \& Andrews, P. W. (2002). Toward a revised evolutionary adaptationist analysis of depression: The social mavigation hypothesis. Journal of Affective Disorders, 72, 1-14.

Weiner, H. (1908). Notes on an evolutionary medicine. Psychosomatic Medicine, 60, 510-520.

Weregrat, B. (1990). Sociobiolegion psychiatry: A new conceplual framework. Lexington, MS: Lexington.

Wenegrat, B. (1995). Illness and prower. New York: New York University Press.

West-Eberhard, M. I. (2003). Dedopmental plasticity and colution. New York: OxfordUniversity Press.

White, N. F. (1974). Ethology and psychiatry. Toronto: University of Toronto Press.

Whiten, A. \& Byme, R. W. (1997). Machiavellian intelligence Il: Extensions and evaluations. New York: Cambridge University Press.

Williams, G. W., \& Nesse, R. M. (1991). The dawn of Darwinian medicine. Quarterly Review of Biol$0,4 \%, 66,1-22$.

Wilson, D. R. (1998). Evolutionary epidemiology and manic depression. British Journal of Medical Psuchology, $71,375-395$.

Wolpert, L. (19c)y). Malignant sadness: The anatomy of depression. New York: Free Press.

Wright, R. (1994). The moral amimal: The new science of evolutionary psychology. New York: Pantheon Books.

Wrosch, C., Scheier, M. E. \& Carver, C. S. (200;3). The importance of goal disengagement in adaptive self-regulation: When giving up is beneficial. Self and Identity, 2, 1-20.

Wrosch, C., Scheier, M. F., \& Miller, G. E. (2003). Adaptive self-regulation of unattainable goals: Goal disengagement, goal reengagement, and subjective well-being. Personality and Social Psychology Bulletin, 29, 1494-1508.

Yehuda, R., Falliy̧in, S. L., Colier, I. A., Grossman, R., \& Bierer, L. M. (2004). Effects of trauma exposure on the cortisol response to dexamethasone administration in PTSD and major depressive disorder. Psychoneuroendocrinology, 29, 389-404. 